\title{
A Study on the Non-English Majors' Use of Metacognitive Strategies in English Learning
}

\author{
Yue Yan \\ Shanxi Normal University, China
}

\begin{abstract}
With the deepening of education for all-round development, modern education pays more and more attention to how to make students learn with lesser time and energy but being efficient, which, undoubtedly, involves study of a series of problems concerning learning strategies, and theories related to metacognitive strategies are the most suitable and supporting theories to learning strategies. The research aims to discuss what metacognitive strategies are usually used by non-English major students as well as how these metacognitive strategies function. The research has been carried out in the form of a questionnaire, about 100 non-English majors from Yuncheng University attended the questionnaire. The results show that metacognitive strategies and cognitive strategies always work together. And with the help of these metagnitive strategies, students can find suitable ways to learn the language, they can think and work more independently, making learning plan in a more reasonable way, which help them become the host of learning, and be a successful learner. The author hopes that her research findings may be of some significance in English teaching and learning although there are still some deficiencies and the need of further research.
\end{abstract}

Index Terms - metacognitive strategies, questionnaire, suggestions

\section{INTRODUCTION}

\section{A. The Background of the Study}

In recent years, more and more researchers in the field of education have paid attention to learning instead of teaching, to students instead of teachers. And learning strategies start to attract their attention, too. In the studies about learning strategies, researchers began to realize the importance of metacognitive strategies and found that it's very important for English learners to use proper metacognitive strategies in their learning process. Bandura (2001) maintains that the quality of students' knowledge about how to learn influences their engagement in learning, and consequently, their learning achievements. Therefore, as instructions guiding students in their learning, metacognitive strategies are of great importance in English teaching and learning research field. Students are suggested to use proper metacognitive strategies in their English learning, which can help learn the language more efficiently and better.

However, in the actual practice of English learning, most students are not quite skillful at using learning strategies. They probably neither have successful learning strategies nor know how to use them properly. Therefore, on the basis of the researches done in the field, more attention should be paid to the study of metacognitive strategies and more work needs to be done to find out the current situation of students' knowledge and ability to use these strategies. Therefore, here in this paper, the author will carry out a study on the current situation of metacognitive strategy application among non-English majors through a questionnaire, and try to find out the relationship between the use of metacognitive strategies and students' English grades and performance in English learning. She hopes that her findings can offer some help for students to have good command of metacognitive strategies and then learn English with lesser time and energy but efficiently.

\section{B. The Aim and Significance of the Study}

The aim of education is to help students learn to think. Each process of education has to be the natural process which initiated by students' cognitive and emotional experience. The cultivation of the metacognitive monitoring competence has been treated as a useful way to teach students how to study and help teachers improve their teaching quality, and then the capacity of metacognitive monitoring can train students in their learning to think, learning in different scenarios and choosing effective learning strategies to enhance self-learning. Metacognitive strategies not only enriched and developed the theory of cognitive psychology theoretically, but in practice played an important role in developing students' intelligence and teaching students how to learn. Knowing the cognitive strategies, the students can quickly get used to higher professional education and become people who know how to study. That is to say, students can develop their ability to analyze and solve problems independently in learning English and value their own progresses objectively. As for teachers, it is of positive significance to apply metacognitive strategy to classroom-based teaching in that it can help students to extricate themselves from mechanical learning into autonomous learning.

\section{The Structure of the Study}


The paper consists of six parts. The first part introduces the background, significance, and structure of the study. Part two mainly presents the literature review which is related to the theory about learning strategies, metacognitive strategies and cognitive strategies; it is a major theoretical part of this article: it states the classification of leaning strategy, and introduces the definition, the classification, as well as the function of metacognitive strategies. Part three states the research methodology and designing, including the research purpose, subjects, research instrument, and research procedure and data collection. Part four aims to analyze the results, which may be helpful, to some extent, for students to learn English well, and aspiring for teachers to improve their teaching quality. Part five is the implications of the study, the author puts forward some suggestions for both the students and the teachers. In the last part, the author draws the conclusion of the thesis. Besides, some limitations of the study and suggestions on the further research were also given in this part.

\section{LITERATURE REVIEW}

In 1987, O'Malley and Chamot put forward three categories of learning strategies according to the information-processing theory, and they thought that metacognitive strategies play a important role in the improvement of English grades and the ability of autonomous learning. In 1996, in China, Wen Qiufang firstly discussed the regulatory function of metacognitive strategies. Other researchers also pay attention to the metacognitive strategies later, and they affirm the role of metacognitive strategies. Recently, the importance of learning strategies, especially metacognitive strategies has attracted great interest among researchers, teachers and linguists in English teaching field. Students also want to learn English efficiently and well. Thus, the study on metacognitive strategies domain is significant. In this part, the classification of learning strategies is stated in brief. Moreover, the definition, the classification, and the function of metacognitive strategies are also introduced.

\section{A. The Classification of Learning Strategies}

In 1970s, some researchers such as Rubin (from the United States), Naiman, Frohlich and Todesco (from Canada) began the research of second language learning strategy (Chamot and O'malley, 1990). Since then, second language learning strategy has gradually become a hot topic. In recent decades, many researchers have pointed out that it is impossible to achieve satisfied teaching effect only by one good teaching method, no matter what kind of method it is, whether it is grammar, translation, communicative, or the direct method etc. So when they study pedagogy, they also focus on the study of how to learn.

Chamot (1987) said that "learning strategies are techniques, approaches or deliberate actions that students take in order to facilitate the learning, recall of both linguistic and content area information." Rubin (1987) thinks that "learning strategies are strategies which contribute to the development of the language system which the learner constructs and affects learning directly."

Nowadays, learning strategies are mainly divided into three major categories, they are: cognitive strategies, metacognitive strategies, and social/affective strategies (Brown and Palinscar, 1982; Chamot and O'malley, 1990).

1.1 Cognitive strategies

Cognitive strategies are more directly related to a specific task or a learning object and may not be applicable to different types of tasks, they refer to the steps or operations used in problem solving, which need direct analysis, transformation or synthesis of learning materials. They have an operative or cognitive-processing function. They may be limited to the special type of task in the learning activity. Typical strategies that have been discussed in the cognitive category for listening and reading comprehension are:

(1) rehearsal, or repeating the names of items or objects that have been heard;

(2) organization, or grouping and classifying words, terminology, or concepts according to their semantic or syntactic attributes;

(3) inference, or using information in oral text to guess the meaning of the new linguistic items, predict outcomes, or complete missing parts;

(4) summarizing, or intermittently synthesizing what one has heard to ensure the information has been retained;

(5) deduction, or applying rules to understand language;

(6) imagery, or using visual images to understand and remember new verbal information;

(7) transfer, or using known linguistics information to facilitate a new learning task;

(8) elaboration, or linking ideas contained in new information or integrating new ideas with known information. (Liu Runqing and Wen $\mathrm{Xu}, 2011)$

1.2 Metacognitive strategies

According to Oxford (1990), metacognitive strategies refer to the "overall control over the learning process through reasoning, planning, monitoring, and self-evaluation." (P. 43). As the focus of this thesis, detailed discussion on metagonitive strategies will be given in the below in 2.2 .

1.3 Social/Affective strategies

Social/Affective strategies refer to strategies involving the interaction with other people or the management of affection. Like metacognitive strategies, they are thought to be more applicable to various tasks (Chamot and O'Malley, 
1990). Social/affective strategies concern the ways in which learners choose to interact with other learners and native speakers. The strategies that would be useful in listening comprehension are:

(1) cooperation, or work with one or more peers to solve a problem, pool information, check notes, or get feedback on a learning activity;

(2) questioning for clarification, or asking a teacher or other native speaker for repetition, paraphrase, explanation and/or examples

(3) self-talk, or using mental control to assure oneself that a learning activity will be successful or to reduce anxiety about a task.(Liu Runqing and Wen $\mathrm{Xu}, 2011$ )

\section{B. Metacognitive Strategies}

2.1 Definition of Metacognitive strategies

As has been mentioned in the above, metacognitive strategies refer to the "overall control over the learning process through reasoning, planning, monitoring, and self-evaluation." They are knowledge and regulation about cognitive phenomena, the knowledge enables individuals to "plan, sequence, and monitor their learning in a way that improves performance." (Oxford, 1990, P.43).

Metacognitive strategies do not like the confinement of cognitive strategies, they are more universal among various tasks. So, it's natural that they have the highest superiority.

Metacognitive strategies make use of knowledge about cognitive processes and constitute attempts to regulate language learning by means of planning, monitoring, and evaluating. They have an executive function. (Liu Runqing and $\mathrm{Wen} \mathrm{Xu}, 2011$ ).

The following form can explain the concept of metacognitive strategies well.

\begin{tabular}{|c|c|}
\hline \multicolumn{2}{|c|}{ Metacognitive strategies } \\
\hline strategies & description \\
\hline plan/organize & $\begin{array}{l}\text { Before beginning a task: } \\
\text { - set goals } \\
\text { - plan the task or content sequence } \\
\text { - plan how to accomplish the task (choose strategies) } \\
\text { - preview a text }\end{array}$ \\
\hline $\begin{array}{l}\text { monitor/identify } \\
\text { problems }\end{array}$ & $\begin{array}{l}\text { While working on a task } \\
\text { - check your progress on a task. } \\
\text { - check your comprehension as you use the language. Do you understand? If not, what is the problem? } \\
\text { - check your production as you use the language. Are you making sense? If not, what is the problem? }\end{array}$ \\
\hline evaluate & $\begin{array}{l}\text { After completing a task: } \\
\text { - assess how well you have accomplished the learning task. } \\
\text { - assess how well you have used learning strategies. } \\
\text { - decide how effective the strategies were } \\
\text { - identify changes you will make the next time you have a similar task to do. }\end{array}$ \\
\hline $\begin{array}{l}\text { manage your own } \\
\text { learning }\end{array}$ & $\begin{array}{l}\text { - determine how you learn best. } \\
\text { - arrange conditions that help you learn } \\
\text { - seek opportunities for practice. } \\
\text { - focus you attention on the task. }\end{array}$ \\
\hline
\end{tabular}

2.2 The Classification of Metacognitive Strategies

A. Oxford (1990) pointed out three sub-strategies for Metacognitive Strategies:centering your learning, arranging and planning your learning, and evaluating your learning.

B. Anderson (1991) subsumed these strategies into five steps: preparing and planning for effective learning, selecting and using particular strategies, knowing how to monitoring strategy use, learning how to orchestrate various strategies, and evaluating strategy use and learning.

C. According to Brown and Palincsar (1982), these strategies involved reflecting, planning, and monitoring in the process of learning as well as self-evaluating after the learning activities.

From the above classifications of metacognitive strategies, we can see all of them involve planning and evaluating of learning, which shows that in the process of English learning the planning and evaluating are really important.

2.3 The Function of Metacognitive Strategies

In general, using these metacognitive strategies properly, learners can promote their learning autonomy. Metacognitive strategies can help students learn English with lesser time and energy but more efficiently, helping them finding suitable ways of learning. Besides, in this way, they learn to think and learn independently, make plans reasonably, and then become the host of learning and a successful learner.

People often say that a good plan is a half of success. When students use metacognitive strategies, they often make a plan. For example, they may set the amount of finishing tasks or the goals of accomplishing, the ultimate time of finishing the task, planning how to accomplish the task. Studying English with these plans, students can learn with full attention and achieve the goals and finish the tasks in time. They also can take easy to finish them, because they already have planned the procedure. 
Using metacognitive strategies, students can check their progress on a task, if the progress is too slow or too quick, they can make relative adjustments. Students also check their comprehension when they use the language. Do they understand? If not, what is the problem? Through these checking, students can learn English well.

After finishing a task, students will assess how well they have completed the learning task and how well they have used learning strategies. They will decide how effective the strategies were, and in order to improve themselves, they will identify the changes they need to make the next time when they have a similar task to do. Then, they will choose the best strategies to finish similar task next time. With these experiences, students can learn English easily and excellently.

\section{RESEARCH DESIGN}

In this paper, the author adopts the ways of questionnaire to study non-English majors' application of metacognitive strategies in English learning. In this part, the design of the questionnaire, the research purpose, subjects, research instrument, and research procedure and data collection will be introduced.

\section{A. Research Purpose}

This study aims to learn the application of metacognitive strategies in English study among non-English majors in Yuncheng University, and the relations between the use of metacognitive strategies and students' English grades. The author aims to investigate the following questions: 1) whether the subjects use any metacognitive strategies in their English learning; 2) what are these metacognitive strategies; and 3) what's the function of these metacognitive strategies? And the author hopes that the study can enlighten students in English study, and then students can learn English easily and effectively through metacognitive strategies.

\section{B. Subjects}

The study involved a sample of 100 non-English major students at Yun Cheng University. The students were randomly chosen. Most students have been studying English for about 8 years (English is their foreign language), with 3 years at junior high school and 3years at senior high school respectively, and 2 years at college.

\section{Research Instrument}

The study mainly adopt the form of questionnaire, as the most widely used method in empirical research, questionnaire is so convenient. The questionnaire is sorted out by the author herself.

The questionnaire includes 3 parts. The first part contains information of students, including name, major and their scores of CET4 and CET6. The second part includes 33 items, the 33 items is classified into 3 categories, the items are the questions in appendix (item 1-7 are about planning strategies, 8-28 controlling strategies, and 29-33 evaluating strategies). After every topic, there are 5 answers, they are namely "completely or nearly completely don't fit me"; "often don't fit me", "sometimes fit me", "often fit me", "completely or nearly completely fit me". Because Chinese is the students' mother tongue, and in order to let the participants understand the survey items correctly, the questions was designed in Chinese instead of English. In the third part, there are several outlines; students can write some metacognitve strategies that they think are very useful to them.

\section{Research Procedure and Data Collection}

The author designed and made the questionnaire in advance. In classroom for individual study, the questionnaire paper were handed out to the subjects, then collected after they have finished.

Before the students answer the questionnaire paper, the author made clear the purpose of her study and the way to answer the paper. In the end, all the questionnaire papers were collected and valid. After that, data were collected on the basis of the questionnaire and analyzed.

\section{DATA ANALYSIS AND DisCUSSION}

This part presents the current situation of the application of metacognitive strategies in English study among non-English majors in Yuncheng University, which are mainly investigated through the 33 items in the questionnaire, among which item 1-7 are about planning strategies, 8-28 controlling strategies, and 29-33 evaluating strategies. The relations between the use of metacognitive strategies and students' English grades has also been presented here.

\section{A. Analysis of the Current Situation of the Application of Metacognitive Strategies}


TABLE 1

THE APPLICATION OF METACOGNITIVE STRATEGIES IN ENGLISH STUDY

\begin{tabular}{|c|c|c|c|c|c|c|c|}
\hline \multirow{2}{*}{$\begin{array}{l}\text { Categories of } \\
\text { metacognitive } \\
\text { strategies }\end{array}$} & \multirow[t]{2}{*}{ Item } & \multicolumn{6}{|c|}{ Number and percentage of each answer on the basis of the 3 categories } \\
\hline & & & $\begin{array}{l}\text { completely or } \\
\text { nearly completely } \\
\text { don't fit me }\end{array}$ & $\begin{array}{l}\text { often don't } \\
\text { fit me }\end{array}$ & $\begin{array}{l}\text { sometimes } \\
\text { fit me }\end{array}$ & $\begin{array}{l}\text { often fit } \\
\operatorname{me}(\%)\end{array}$ & $\begin{array}{l}\text { completely or } \\
\text { nearly completely } \\
\text { fit me }(\%)\end{array}$ \\
\hline \multirow[t]{2}{*}{ planning } & \multirow[t]{2}{*}{$1-7$} & number & 0 & 0 & 99 & 201 & 400 \\
\hline & & percentage $(\%)$ & 0.00 & 0.00 & 0.14 & 0.29 & 0.57 \\
\hline \multirow[t]{2}{*}{ controlling } & \multirow[t]{2}{*}{$8-28$} & number & 148 & 402 & 655 & 600 & 295 \\
\hline & & percentage $(\%)$ & 0.07 & 0.19 & 0.31 & 0.29 & 0.14 \\
\hline \multirow[t]{2}{*}{ evaluating } & \multirow[t]{2}{*}{$29-33$} & number & 343 & 140 & 10 & 7 & 0 \\
\hline & & percentage $(\%)$ & 0.69 & 0.28 & 0.02 & 0.01 & 0.00 \\
\hline
\end{tabular}

In the first table, the author describes the number and percentage of each answer on the basis of the 3 categories. For example, we can see that the total number of the answers for questions 1-7 is 700 , among which the number for the answer "completely or nearly completely fit me" is 400. In the same way, the number for this answer is 295 from its total number of 1100 for items 8-28, and 0 for items 29-33. Then, the author calculates each answer' percentage of the 3 kinds of categories respectively on the basis of number of each answer. For example, the number of "completely or nearly completely fit me" is 400 for items $1-7$, and there are 700 answers from item $1-7$, so, the percentage of "completely or nearly completely fit me" is 0.57 by the means of $400 / 700$. We can know from the table that the percentage of the answer of "completely or nearly completely fit me" is 0.00 from item 29-33, and the item 8-28 is only 0.14 , and the item $1-7$ is 0.57 . So, the author finds that the students we investigated do not have a good command of metacognitive strategies. In addition, the table tells us that students usually make a plan when they learn English, which has been shown from the percentage of the condition "often fit me" is 0.29 . "Completely or nearly completely fit me" is 0.57, which is the highest percentage from items1-33. But students can not monitor and evaluate their learning well when they learn English, which can be seen from the statistics about item 29 to item 33, the percentage of "completely or nearly completely fit me" is 0.00 , and "often fit me" is 0.01 . Besides, although many students can make plans when they learn English, the percentage of "completely or nearly completely fit me" is not up to 0.6. All in all, the students we investigated are not good at mastering metacognitive strategies.

\section{B. Analysis of the Relations between Metacognitive Strategies Use and Students' English Grades}

TABLE 2:

THE RELATIONS BETWEEN THE USE OF METACOGNITIVE STRATEGIES AND STUDENTS' ENGLISH GRADES

\begin{tabular}{|l|l|l|l|l|l|}
\hline \multirow{2}{*}{ English grades } & \multicolumn{4}{|l|}{ The conditions of English grades when students choose the 5 answers which answer is most } \\
\cline { 2 - 6 } & $\begin{array}{l}\text { completely or nearly } \\
\text { completely don't fit me }\end{array}$ & $\begin{array}{l}\text { often don't fit } \\
\text { me }\end{array}$ & $\begin{array}{l}\text { sometimes fit } \\
\text { me }\end{array}$ & $\begin{array}{l}\text { often fit } \\
\text { me }\end{array}$ & $\begin{array}{l}\text { completely or nearly } \\
\text { completely fit me }\end{array}$ \\
\hline excellent & & & & & $\sqrt{ }$ \\
\hline good & & & & $\sqrt{ }$ & \\
\hline middle & & $\sqrt{ }$ & & & \\
\hline pass & & & & & \\
\hline bad & $\sqrt{ }$ & & & & \\
\hline
\end{tabular}

Table 2 is the correlation between students' English grades and the use of metacognitive learning strategies. What we can see from table 2 is that when a student's English grade is bad, he/she chooses "completely or nearly completely don't fit me" most; when a student's English grade is at middle level, he/she chooses "often don't fit me" or "sometimes fit me" most; when a student's English grade is good, he/she chooses "often fit me" most; when a student's English grade is excellent he/she chooses "completely or nearly completely fit me" most. From the above table we can know that students' score is related to their application of metacognitive strategies in general. And, we also can draw the conclusion that there is a positive relation between metacognitive strategies and English grades, and the findings prove that the more metacognitive strategies they use the higher level of English competence the students have, and the higher scores they get. It shows that there is a positive relationship between the application of metacognitive strategies and English ability.

\section{Summary}

From the above analysis we can see that the subjects of the survey who have been investigated do not have a good command of metacognitive strategies. In addition, there is a positive correlation between English grades and the use of metacognitive learning strategies. Of course that is not always the absolute case. It does not mean that your English grades must be excellent as long as you use all kinds of metacognitive strategies. But the absolutely thing is that if you do not use metacognitive strategies, your English grades must be bad.Therefore, we may draw such a conclusion that we should use metacognitive strategies in English learning; these strategies can help us learn English more efficiently and better. Just as a proverb says "good ways are half of success."

\section{IMPLICATIONS OF THE STUDY}


Based on the above empirical research findings, we have claimed that ineffective students do suffer from lack of some kind of knowledge about metacognitive strategies. Therefore, enhancing learners' meatcognitive strategies is necessary in the vocational college English teaching and learning. Teachers should take measures to arouse students' interest in English and foster their metacognitive strategy knowledge. In consideration of the above results of the questionnaire, there are some suggestions for English teachers as well as foreign language learners.

\section{A. Suggestions for Students}

As for the students, at first, students should practice to use metacognitive strategies in learning English. In order to learn English easily and effectively, students are required to master some metacognitive strategies and then use them in their learning process. These metacognitive strategies may enable the students to check what they know and what they do not know, thus realize their own problems and gain confidence. With the knowledge, learners can learn English better. Besides mastering certain metacognitive strategies, learners can learn more autonomously under reasonable self-regulation.

\section{B. Suggestion for Teachers}

Teacher should try their best to help students develop a more reflective and self-directed approach to learning their new language. Teachers also guide college students to improve and expand their knowledge about learning so that they may become autonomous in the learning of their new language. Flavell (1979) addressed that knowledge about metacognitive strategies is the basis for learning process. With the metacognitive strategy knowledge, they can arrange their learning process in a smooth way and handle all kinds of learning problems easily.

Therefore, teachers should improve students' strategy awareness and the implementation of the strategy training in English teaching. The application of metacognitive strategy and cognitive strategy is beneficial to autonomous learning, to be up to the standard of English Course Requirements for non-English Majors. In order to fully exploit the latent potentialities of college students, in the course of putting the cognitive tactics into effect, the student centered, meaningful training model should be emphasized, promoting writing together with reading. Because the society is always developing and the study models are always changing, English learners must learn to how to learn. Therefore, it's very necessary to train students' metacognitive ability. It's necessary to develop English learners' metacognitive awareness, to combine metacognitive strategy with cognitive strategy and social-emotion strategy, and to train the metacognitive strategy directly and explicitly. An significance of the current research on self-regulation is to improve students' self-regulated learning in schools. The direct way to promote self-regulated learning is that teachers teach students learning strategies, and the indirect way is to create a learning environment that enables students to practice self-regulation.

\section{CONCLUSIONS}

It turned out that successful language learners own their special learning ways. Stern (1975) and Rubin (1975) were probably among the first researchers who brought up the idea of successful language learners, perhaps, the idea can help us understand the nature of language learning better, meanwhile, it can make us learn language quickly and easily.

Metacognitive strategies are one major type of learning strategies, the ways to achieve them is to plan, monitor, and evaluate. They can help language learners do better and facilitate their learning process.

In order to learn the application of metacognitive strategies in English study among non-English majors in Yuncheng University, and the relations between the use of metacognitive strategies and students' English grades. The author investigated 100 non-English majors' students in Yun Cheng University by means of a questionnaire. According to the results of the investigation, the author finds that the students who have been investigated do not have a good command of metacognitive strategies. In addition, there is a positive correlation between English grades and the use of metacognitive learning strategies. The author hopes that her findings will be helpful for both students and teachers in the school where she carried out the study and further more it may be helpful to promote the effect of English teaching and learning in other colleges and universities.

Of course the study has its own limitations. Firstly, as the limitation of time and energy, the present study only conducted the non-English majors and leaving the English majors unexplored, so inferences and conclusion draw from the results of the study may unsuitable to other population with different background. Hope more study may focus on metacognitive strategy. Secondly, the number of the subject is 100 which is relatively small in the present study. Therefore, it is not sure if the results of the present study would occur with a much lager number of subjects in foreign language context. Besides, the study carried out only in one college. So the findings of the present study could not be applicable to the whole Chinese context. Thirdly, the validity and reliability of the questionnaire is not enough. More energy and time should spend to modify and improve it.

Besides, the conclusions generated from this present study are not final results. It is just a little step in the course of metacognitive strategy knowledge. More complex and difficult problems need to be solved. For example, do good learners develop the metacognitive strategies in a natural way? How do students gain their metacognitive strategies? Is there any rule that students can follow in the use of metacognitive strategies? ... The author hopes that further studies would deal with these questions and metacognitive strategies in a natural way. 
APPENDIX

非英语专业学生英语学习元认知策略使用现状调查表

年级: 大一 $($ ) 大二( ) 大三 $($ )

性别: 男( ) 女( )

你在班上的英语成绩: 优( ) 良( ) 中 ( ) 及格 $($ ) 差 $($ )

下面是常用的英语学习元认知策略, 请根据数字所代表的意思, 在表格右端的数字上划一横线。所选数字一 定要如实描述你的学习情况。请根据自己的实际做法填写。

谢谢合作!

1. 完全或几乎完全不符合我的情况。

2. 通常不符合我的情况。

3. 有时符合我的情况。

4. 通常符合我的情况。

5. 完全或几乎完全符合我的情况。

\begin{tabular}{|c|c|c|c|c|c|}
\hline 1. 我学习外语有明确的目标。 & 1 & 2 & 3 & 4 & 5 \\
\hline 2. 我详细地安排自己的学习时间、学习进程, 以保证有充分的时间学英语。 & 1 & 2 & 3 & 4 & 5 \\
\hline 3. 除了完成老师的作业外，我有自己的自学计划。 & 1 & 2 & 3 & 4 & 5 \\
\hline $\begin{array}{l}\text { 4. 我的自学计划通常比较简单, 一般只考虑做什么, 其他内容, 诸如怎么做什么 } \\
\text { 时候做, 怎样做以及为什么要这样做, 我都不考虑。 }\end{array}$ & 1 & 2 & 3 & 4 & 5 \\
\hline 5. 我很认真地制定自学计划, 计划很详细, 但不能认真、按时执行。 & 1 & 2 & 3 & 4 & 5 \\
\hline 6. 我经常探索适合自己的英语学习方法。 & 1 & 2 & 3 & 4 & 5 \\
\hline 7. 进行某项学习活动之前, 我总喜欢想一想进行这项活动的目的是什么。 & 1 & 2 & 3 & 4 & 5 \\
\hline 8. 我能自觉地预习、复习。 & 1 & 2 & 3 & 4 & 5 \\
\hline 9. 我能专心听老师讲课。 & 1 & 2 & 3 & 4 & 5 \\
\hline 10. 我在进行某项语言活动时注意力维持的时间长。 & 1 & 2 & 3 & 4 & 5 \\
\hline 11. 我常注意听别人 (老师、同学) 用英语说话。 & 1 & 2 & 3 & 4 & 5 \\
\hline 12. 我在听英语时, 能听出他人犯的错误。 & 1 & 2 & 3 & 4 & 5 \\
\hline 13. 我在用英语时, 知道我在什么地方还未弄懂。 & 1 & 2 & 3 & 4 & 5 \\
\hline 14. 我在用英语时, 知道什么地方犯了错误。 & 1 & 2 & 3 & 4 & 5 \\
\hline 15. 我寻找多种途径用英语。 & 1 & 2 & 3 & 4 & 5 \\
\hline 16. 我尽量通过多种渠道 (英文报纸、杂志、收音机、电视、因特网等) 学习英语。 & 1 & 2 & 3 & 4 & 5 \\
\hline 17. 我积极参与英语课堂活动。 & 1 & 2 & 3 & 4 & 5 \\
\hline 18. 我在英语课堂活动中经常充当主要角色。 & 1 & 2 & 3 & 4 & 5 \\
\hline 19. 我要分析学习任务的类型及所需要的技巧。 & 1 & 2 & 3 & 4 & 5 \\
\hline 20. 面对不同的学习任务, 我能运用恰当的学习策略。 & 1 & 2 & 3 & 4 & 5 \\
\hline 21. 我常与教师或其他同学交流学习外语的体会和经验, 了解他人的学习方法。 & 1 & 2 & 3 & 4 & 5 \\
\hline 22. 我能在学英语的过程中发现、总结错误，找出原因并从中有所收获。 & 1 & 2 & 3 & 4 & 5 \\
\hline 23. 我常思考最佳的、最有效的英语学习方法。 & 1 & 2 & 3 & 4 & 5 \\
\hline 24. 交作业、交试卷前我仔细检查。 & 1 & 2 & 3 & 4 & 5 \\
\hline 25. 我听英语时，知道什么地方没听懂。 & 1 & 2 & 3 & 4 & 5 \\
\hline 26. 我常思考学习英语中取得进步的原因, 不断总结外语学习的成功经验。 & 1 & 2 & 3 & 4 & 5 \\
\hline 27. 当别人听不懂我说的英语时, 我反省自己哪儿说错了。 & 1 & 2 & 3 & 4 & 5 \\
\hline 28. 学了东西后, 我检查自己是否真正掌握了。 & 1 & 2 & 3 & 4 & 5 \\
\hline 29. 我能正确评价自己学习英语进步的情况, 从而找出薄弱环节和改进的措施。 & 1 & 2 & 3 & 4 & 5 \\
\hline 30. 我能正确评价自己的英语水平和知识的掌握情况。 & 1 & 2 & 3 & 4 & 5 \\
\hline 31. 我常评价自己的学习策略, 从而找出存在的问题和解决方法。 & 1 & 2 & 3 & 4 & 5 \\
\hline 32. 我常反思自己的学习活动、反思学习效果欠佳的原因。 & 1 & 2 & 3 & 4 & 5 \\
\hline 33. 我根据自己的学习效果不断调整自己的学习计划, 改进学习方法。 & 1 & 2 & 3 & 4 & 5 \\
\hline
\end{tabular}

\section{REFERENCES}

[1] Anderson, J. R. (1991). Is human cognition adaptive? Behavioral and Brain Sciences, 14, 471-517.

[2] Brown, A. L., \& Palinscar, A. S. (1982). Inducing strategies learning from texts by means of informed self- control training. Topics in Learning and Learning Disabilities, 2, 1-17.

[3] Bandura. (2001). Social cognitive theory: An agentic perspective. Annual Review of Psychology, 52, 1-26.

[4] Chamot, Rubin. (1987). Web Transcription Tool. http://www.doc88.com/p-99854 -47736640.html (accessed 31/3/2012).

[5] Carrel, P. L. (1989). Metacongnitive Strategy Training for ESL Reading. TESOL Quarterly, 3, 121 - 134.

[6] Flavell, J. H. (1979). Metacognition and Cognitive Monitoring: A New Area of Cognitive Developmental Inquiry. American 
Psychologist, 10, 906-909.

[7] Liu Shaolong, Xiao Shanxiang. (2002). The Cognition of Metacognition and Language Learning. Journal of Xi'an International Studies University, 4, 37-39.

[8] Liu Runqing, Wen Xu. (2011). Linguistics: A New Coursebook. Beijing: Foreign Language Teaching and Research Press.

[9] McNeil, J. (1987). Reading Comprehension. Glenview, IL: Scott, Foresman and Company.

[10] O'Malley \& Chamot. (1990). Learning strategies in second language Acquisition. Cambridge: Cambridge University Press.

[11] Oxford. (1990). Language Learning Strategies: What Every Teacher Should Know. New York: Newbury House.

[12] Paris, S. \& Oka, E. (1986). Children's Reading Strategies Metacognition, and Mo-tivation. Developmental Review, 6, 25-26.

[13] Stern and Rubin. (1975). Web Transcription Tool. http://tesl-ej.org/ej26/a5.html (accessed 5/9/2003).

[14] Thompson I \& J Rubin. (1996). Can strategy instruction improve listening comprehension. Foreign Language Annals, 3, 33-342.

[15] Wen Qiufang. (1993). English Learning Theories. Shanghai: Shanghai Foreign Language Education Press.

[16] Wen Qiufang. (1996). The Structure, Characteristics and Regulations on the System of English Learning Strategies. Foreign Language Teaching and Research, 1, 6-60.

Yue Yan was born in Lin Fen, China in 1993. Now, she is a linguistic postgraduate, she studies at Shanxi Normal University in Shanxi province, this is her second year at this University.

She has been a teacher at a senior high school in 2015. She is currently a postgraduate at Shanxi Normal University, her research interests include translation and language learning strategies. 